\title{
The Validity of Modigliani-Miller Theorem at the Commercial Banking Industry of Jordan
}

\author{
MOHAMMED IBRAHIM SULTAN OBEIDAT \\ Accounting Department \\ Jadara University \\ Irbid-JORDAN \\ ORCID ID: https://orcid.org/0000-0002-2730-1415
}

\begin{abstract}
The study objects for investigating whether the findings of Modigliani-Miller Theorem (1958-1963), are valid in the environment of listed commercial banks at Amman Stock Exchange. To achieve the objective of the study, data of 13 out of a total of 15 listed commercial banks, covering the period (2010-019), had been collected and tested, using descriptive statistics and the ordinary least square method. The analysis of the data and hypothesis testing leads to an existence of a significant positive impact of debt on the firm market value. Opposite to Modigliani-Miller theorem, the study finds that debt is relevant to the bank market value, and it has a positive significant on bank market value. The conclusion is not in conflict with the finding of Modigliani-Miller 1958, where the authors assumed free tax, while the commercial banks of Jordan are subject to tax. Therefore, the finding of the current study are consistent with the adjusted Modigliani-Miller 1963 theory. More studies taking into consideration different industries and different business environments are strongly recommended.
\end{abstract}

Key-words: - Capital structure, Debt, Equity, Financial Leverage, Firm Market Value, and Modigliani-Miller Theorem.

Received: December 15, 2021. Revised: May 20, 2021. Accepted: May 27, 2021. Published: June 1, 2021.

\section{Introduction}

The capital structure modern thinking started from the announcement of Modigliani-Miller theorem (1958), and the amendment made on 1963. The theory stated that the firm market value is irrelevant of the way the capital structure is formed. Modigliani-Miller theorem (1958), stated that whether the capital structure of firms consists of more debt and less equity, or in opposite, more equity and less debt, the issue is not a matter for the market value. Actually, the capital structure formation is related to the basic accounting equation, where assets should be equal to liabilities and equity. This means that the assets of a business organization are financed or funded by only liabilities or equity or, by a mix of debt and equity. Based on Modigliani-Miller (19581963), the proportions of equity or debt in the capital structure, do not affect the firm value, whatever the proportion of debt or equity is high or low. The decision of how much to use debt, and how much assets to be financed by equity is still ambiguous and confusing, and till now, no formula or theory can determine the optimal mixture of these two resources of invested capital in assets. Several theories appeared regarding the capital structure of firms, starting from Modigliani-Miller Theorem (1958), which stated that the firm market value is independent of the capital structure, and no impact of capital structure on the market value of firms.

Improving the financial performance of business organizations, icluding commercial banks, is required nowadays than before. The efficiency and the financial performance of business organizations, and therafter increasing the firm market value, can be improved by adopting many policies and procedures including resource allocation problems (Bao, Zeng, and Wang, 2017), and by investing more in capital through borrowing, since more borrowings is irrelevant to market value (Modigliani \& Miller, 1958). In addition, different policies can be adopted by firms to be more familiar with systematic risk (Duan, 2019), since measuring systematic 
risk to deal with this situation at a better form, improves the entire performance, and reflected at a better market-value. Modigliani-Miller theorem (1958), stated that with well functioning markets, the market value of a firm, is not affected by the composition of its capital structure (Tudor,et al, 2013). In brief, the theory states that debt ratio in the capital structure, has no impact on the market value. The theory had been tested later by several authors, where some of these investigations found some different and opposite findings of Modigliani-Miller (1958), theorem. Because some studies, next to the issuance of Modigliani-Miller theorem, announced different findings than than that of ModigianiMiller, more studies for different firms and industries, in different countries, are required to investigate more and more, the relationship between capital structure composition and firm market value.

The current study came as a reaction to the comments and findings that issued next to the issuance of Modigliani-Miller Theorem. In more details, because there are confronting findings of the studies made based on the findings of Modigliani-Miller theorem, the current study came as an attempt to test the findings of that theory at the commercial banking industry of Jordan. Moreover, the decision of debt volume in the capital structure of business organizations is still confusing, since some prior studies announced different findings to the findings that are shown by Modigliani-Miller (1958). The capital structure is an important decision, where in this decision, decision makers are required to select the proper debt-equity proportions in the capital structures of their firms, and then achieve better financial performance. Therefore, the problem of the study can be better expressed using the following question; does the composition of debt-equity in the capital-structure of business organizations, affect the firm market value? Despite Modigliani-Miller theorem stated that capital structure composition of debt and equity, is irrelevant to the firm market value, but the theory stated that this irrelevance between capital structure and firm value is based on several assumptions, that practically are unavailable. The answer to the study question requires more and more investigations, and the current study is one attempt underline this questionable issue.
The study stems its importance from the importance of debt existence in the capital structure of business organizations. Using or avoiding debt in the capital structure is an important issue, and in case of debt existence in the capital structure, identifying the optimal ratio of debt to equity is also important, since value maximization is one important objective of corporate firms, and shareholders are very interested with this issue. The importance of the study increases because different confronting findings to the findings of Modigliani-Miller theorem are shown later regarding the effect of debt in the capital structure of corporate firms, on the firm market value.

The current study aims to achieve several objectives. The primary objective of the study is to investigate whether debt in the capital structure, affects the market value of Jordanian commercial banks. In addition, the study objects for determining whether equity has an impact on firm market value, since equity cannot be ignored while debt is analyzed. Moreover, because no enough literature of the two components of capital structure, the study aims to add more literature in this issue and its behavior, especially in developing countries, where this issue had not been given enough attention in research and analysis.

The remainder of the study is organized to be as follows. Section 2, presents the literature review and section 3, considers the prior related research. Section 4, lists the development of the hypotheses, whereas section 5, presents the methodology of the study. Section 6, shows the results and data analysis, whereas the findings of the study are shown in section 7 .

\section{Literature Review}

The litreature review of the study presents information,definiton,concepts,et al, and the main theories of capital structure, with a type of focus on the findings of Modigliani-Miller theorem regarding the capital structure.

\subsection{Capital Structure Definition and Theories}

First of all, it is necessary to clarify the term of capital structure, and the firm market value, starting by the capital structure and ending with the firm market value. The basic accounting equation states that, total assets equal total liabilities and owners' equity, where liabilities is the debt portion in the capital 
structure. This equation refers to the balance between assets in one side and liabilities and equity in the other side. In other words, the basic accounting equation states that the assets of a business organization are financed through owners' equity or through debt, where debt includes both the short and the long-term liabilities. In simple words, all assets are covered only by owners or by creditors.

The term capital structure refers to the proportion of assets that funded by debt (Enow, 2010). In other words, it refers to the proportion of debt (liabilities) or equity to total investments (assets). It is already known to the majority, that there are two primary resources that can be used to finance the assets of a business organization; equity and debt. A firm may depend more on equity but less on debt, while in opposite, another firm may depend more on debt, but less on equity. ModiglianiMiller (1958) theorem, stated that the firm market value is independent of the capital structure, whether a firm depends more or less on debt. In brief, the theory states that using more or less debt in the capital structure of business organizations, the market value will not affected.

Myers (2000), defines capital structure as "The mix of debt and equity securities used to finance real investments". In addition, capital structure, in financial terms, refers to the way a firm finances its assets through the combination of equity, debt, or hybrid securities, (Saad, 2010). Actually no large differences are available among the above three definitions of capital structure. Therefore, based on the above definitions, and on the consideration of other definitions, the author recommends the capital structure to be defined as the mixture of debt and equity used in financing the assets of a business organization.

Several theories are available nowadays regarding the capital structure of corporate firms, but in addition to Modigliani-Miller theorem, the main ideas of three important theories are considered in this context.

The capital structure theory is attributed to Modigliani-Miller theory (1958), and its following adjustments, where the theory states that, the firm value is determined by its productivity and quality of assets, and the market value is irrelevant of the firm capital structure. More details will provided regarding this theory
The trade-off theory states that there is an optimal capital structure, and this optimal capital structure is determined when the marginal benefit of additional unit of debt offset its marginal cost. In other words, the optimal capital structure exists at the point where the benefits of debt offset its cost. In brief, the trade-off theory assumes that firms trade off the costs and benefits of debt and equity financing. Based on this idea, the optimal capital structure can be determined after the accounting for market imperfections including tax, bankruptcy cost, and agency cost (Luigi and Sorin, 2009).

The dynamic tradeoff theory recognizes that financing friction make it sub optimal for business organizations to continuously adjust its leverage to the target. Under the dynamic tradeoff theory, firms are required to weigh the benefits of adjusting capital structure with the adjusting cost, and when the benefits of the adjustment outweighs its cost, the optimal capital structure is determined.

Under the picking order theory, there is no target debt to equity ratio. According to the pecking order theory, firms normally use its internal resources first, before using debt, and finally issue equity when the requirements of investment exceed debt capacity, or it may issue equity under duress (Fama and French, 2005). In other words, under the pecking order theory, firms follow a financing hierarchy to reduce the asymmetry of information between managers inside the firm and shareholders outside the firm (Luigi and Sorin, 2009).

With regard to the market timing theory of capital structure, equity marketing timing is the timing of issuing shares when its valuation is higher than its book value and higher than its past valuation and purchasing shares when the market price or its valuation is law (Baker and Wurgler, 2002).

\subsection{The Modigliani-Miller Theorem}

Noble Prize winners, Franco Modigliani and Merton Miller theorized that the market value of a firm is determined only by its earning power and the risk of its underlining assets, whereas the way the firm finances its assets or the composition of its capital structure doesn't affect its market value. In other words, these two winners of Nobel Prize ignore any effect of the way the capital structure is compromised, on the firm market value. Normally, the capital structure may include more equity and less debt, or in opposite more 
debt and less equity. What Modigliani and Miller theorized means that whether the firm depends more on equity or more on debt in financing its investment, the firm market value will not be affected. They stated that the value of a firm is determined by its real assets and profitability, but not by the way the capital structure is formed (Enow, 2010)

Modigliani-Miller theory is broadly accepted theory regarding the capital structure. It operates under the assumption of perfect market, where several assumptions of perfect market exist such as zero taxes, rational investors, absence of bankruptcy, perfect competition and perfect market (Arulevel and Ajanthan, 2013). The theory states that the capital structure of a firm is not related to its value when the market is perfect. The decision of capital structure is difficult to be taken, since determining the optimal structure by determining the proportions of each of debt and equity is difficult, since no formula or theory exists can determine how much debt and how much equity is to be used in the capital structure.

The Modigliani-Miller theory involves three main propositions as follows (Ahmeti and Prenaj, 015):

1. Proposition 1. A firm's market value is independent of its capital structure. According to this proposition, the capital structure of a firm has no impact on its market value. This assumption refers to independence of a firm's market value of its debt to equity ratio. The proposition involves several assumptions as follows:

The capital market where the securities are traded is perfect. This assumption means that investors can buy and sell securities, have entire knowledge, can receive all information, and know any changes in the information immediately when the change issued. Moreover, the assumption involves zero buying-selling transaction cost, and regarding borrowing against securities, both investors and the firm are equal.

The proposition without the effect of tax. Modigliani and Miller discussed two firms with different capital structure, where one is with debt in its capital structure, and the other is without debt, assuming the cash flows of both firms are similar. As a result they demonstrated that the capital structure has no effect on the market value.
The proposition with the effect of tax. Because of the tax shield effect where interests are excluded from the payment of taxes, those firms with more debt in its capital structure, will be of more market value than those having no or less debt. The tax shield effect leads firms of high debt to pay less taxes than those of less debt. The difference in tax payments will lead to an effects in the firm market value, where levered firms will be more valuable than unlevered firms.

2. Proposition 2 regarding the Rate of Return on Equity. The proposition states that the cost of equity increases with the debt to equity ratio of a firm.

The second proposition without effect of tax argues that because investors are assumed to be rational, the expected return on equity is proportional to the increase in debt to equity ratio. In more details, the expected return on equity is compensated by cheap debt, and as a result, the weighted average cost of capital will remain the same (Ahmeti and Prenaj, 2015).

The second proposition with the effect of tax argues that when Modigliani-Miller theory had been adjusted in 1963, the ratio of corporate tax is equal to the current value of saving from tax. As a result, the weighted average cost of capital declines by the increase in debt percentage in the capital structure. By the existence of tax, firms benefit from the existence of more debt in the capital structure, while the firm market value will increase, where this increase in the firm market value is due to the effect of tax shield.

3. Proposition 3. The market value is independent of the dividend policy adopted by the firm. Modigliani and Miller (1961) argued that the firm market value is independent of its dividend policy, and it is dependent on its earnings and the risk of its assets.

The Market value or market price refers to the price that both purchasers and sellers agree to exchange the share for. The term market capitalization is related also to the term market value, where market capitalization refers to what investors believe a firm is worth. Market capitalization can be determined by multiplying the share market price by the number of shares outstanding. Therefore, the term of firm market value can be found easily by multiplying the firm's share price by the 
number of shares outstanding of that firm. In brief, the firm market value is where sellers and buyers agree to trade a share at a particular price in an efficient stock exchange, where efficient stock exchange means that sellers and buyers have free access to information, and no constraint both the seller and the buyer are subject to, while trading.

\section{Prior Researches}

Actually, many authors investigated the impact of debt in firms' capital structure on market value, but few studies investigated the impact of debt on firm market value. The contribution of Modigliani and Miller (1958), and the following amendments made by the same authors in 1963, was the starting point, but since that time no too much researches investigated this idea in developing countries, where the stock exchange may not be completely efficient, and where no huge number of large firms are traded in such markets. The most recent studies are considered and their main findings are summarized in this context.

A recent important study that carried out by Nguyen et al (2020) investigated the relationship between capitals structure and firm value. The study depended on data of 22 food and beverages firms in Vietnam over the period (2010-2018). The focus in this study was on equity and leverage, despite that additional factors were taken into consideration as control variables. Using the multiple regression method, the study showed that a positive relationship exists between capital structure and firm value. It showed also that firm quality, tangibility, firm growth, GDP growth, each of which, can improve the firm value.

Al-Slehat (2020), investigated the effect of selected variables on firm market value. The purpose of the study was to examine whether financial leverage, size, and assets structure, each of which, has an impact on firm market value. To achieve the purpose of the study, the author gathered and used the data of 13 mining and extracting listed firms at Amman Stock Exchange over 2010-2018. Using the simple linear regression, the study showed no significant impact of financial leverage on firm market value, but it shows that each of size and assets structure has a significant impact on firm value.
A recent study carried out by Al-Nsour and Al-Muhtadi, (2019) for the purpose of investigating the influence of capital structure and profitability on firm's market value. Based on the data of 41, out of a total of 63 listed manufacturing firms at Amman Stock exchange, over the period (2014-2018), and by using the multiple regression method, the study revealed different findings due to the two models used by the authors of the study. When the market value model was used, the results showed that debt to equity ratio has a significant positive effect on market value, while when Tobin's Q model was used, the results showed that no significant effect of capital structure nor profitability on firm's market value.

Aggarwal and Padhan, (2017), examined the impact of capital structure on the firm market value. The study had been applied on 22 listed hotel firms at BSE over the period 2001-2015. Several variables were studied in the study including, firm quality, leverage, size, profitability, tangibility, growth, liquidity, and macroeconomic factors. The study showed a significant relationship of firm value with firm quality, leverage, liquidity, size, and economic growth.

The impact of debt on firms' market value was among the interests of Shanika Ishari and Madhushanka Abeyrathna (2016). The purpose of their study was to investigate the effect of financial leverage on firms market value, and to compare the value of the listed manufacturing in Sri Lanka by using the financial leverage. The data of a sample consisted of 50 listed firms over the period 2011-015, was used to achieve the authors' objectives. Using Pearson correlation, the study found that there is a negative relationship between debt to equity ratio and return on assets, but regression showed a significant effect of debt to equity ratio on return on assets.

Ahmeti and Prenaj (2015) made a review of the Modigliani-Miller theory of capital structure. The purpose of the study was to present the implications, importance, and the theoretical contribution of the theory. The authors of the study mentioned that Modigliani and Miller presented what can be considered the most important theory regarding the corporate structure of capital when they explained the impact of capital structure on firm value. The study mentioned that despite 
this important contribution and the hard effort made in this theory, but the theory remains unclear and found many objections. A critical review and in depth assessment had been made to Modigliani and Miller theory and concluded that the contribution is significant but did not finally prove that the capital structure is entirely irrelevant to the capital structure.

Pouraghajan and Bazugir (2013), carried out a study to examine the impact of capital structure on firm market value. The study was based on information of 58 listed firms at Tehran Stock Exchange over the period 20062010. Using the regression method in the statistical analysis of data, the study found a meaningful relationship between capital structure and firm market value. In addition, the study demonstrated that a meaningful relationship exists between assets growth and firm market value. In opposite, no meaningful relationship had been found between each of revenue growth and firm size in one hand, and the firm market value in the other hand.

Collins, Filibus, and Clement (2012), investigated the relationship between corporate capital structure and corporate market value in Nigeria. The study aimed to explain the relationship between the capital structure and the market value of corporations, and to show whether the existence of debt in the corporate capital structure. The study was based on data covering the period 2005-009 of 39 out of 186 nonfinancial listed firms in Nigeria The regression used in the study showed a significant positive relationship between debt/equity ratio and firm market value, but negative relationship between total debt/total capital ratio and the firm market value exists.

A study carried out in Ghana by Antwil, Emire, and Zhaol (2012), deserves mentioning here in the context. The purpose of the study was to provide evidence on the impact of capital structure on a firm's value. It had been made based on the data of 34 listed firms at Ghana Stock Exchange. Using the ordinary least square method the study revealed that capital structure decision have various implications, where the firm value is one among these implications. Moreover the study recommended that firms are advised to compare between the marginal benefits of long-term debt and the marginal cost of longterm debt before taking the capital structure decision.
Maxwell and Kehinde (2012), carried out a study aiming for providing evidence regarding the impact of capital structure on firm value. The analysis of the study was based on data of 124 listed firms at Nigerian Stock Exchange for the year ended December 31, 2007. The ordinary least square method had been used in data analysis, and revealed that in an emerging economy, equity capital is irrelevant to firm value, whereas long-term debt is found the major relevant variable. Based on its findings, the authors of the study recommended using more long-term debt in the capital structure.

The relationship between capital structure and firm value was among the interests of Adeyemi and Oboh (2011), when they examined the empirical effects of corporate capital structure on firm market value. Actually this study depended on primary and secondary data to test whether capital structure affects the firm market value, when 150 respondents responded to a questionnaire, in addition to secondary data of 90 firms. Descriptive statistics and chi-square methods were used in data analysis. The study demonstrated that a positive relationship exists between the capital structure decision and firm value.

\section{Study Hypotheses}

Modigliani and Miller (1958), revealed that in a frictional World, financial leverage is unrelated to firm value, but in countries of tax deductible interest payment, the capital structure and firm value are related. In contrast, other theories such as trade-off theory (Myers, 1984), and Pecking order theory (Myers and Majluf, 1984), demonstrated that when market imperfections exist, the issue will be different. In addition to equity part in the capital structure, some prior researches demonstrated that debt leads to an increase in firm value for low-growth firms. For example, Jensen (1986) demonstrated that when a firm has more internally generated funds than positive net present value projects, managers find themselves enforced to payout funds that might otherwise invested in negative net present value projects. In addition, Stulz (1988)and Kyaw (2006), demonstrated that debt may has positive or negative effect on firm value. Antwi and Zhao, (2012) also found that equity capital is relevant to firm market value in an emerging economy, and long-term 
debt is the major determinant of firm value. Nguyen and others, (2020) demonstrated that capital structure including debt and equity, has a positive relationship with firm market value. Moreover, Adeyemi and Oboh (2011), found that the capital structure has a positive effect on firm market value.

Based on the related literature review and on the findings of some prior related researches, the following hypotheses had been developed, in its null form.

Ho1. The debt portion in the capital structure of the listed commercial banks at Amman Stock Exchange, has no impact on the market value of banks.

Ho2. The equity portion in the capital structure of listed commercial banks at Amman Stock Exchange, has no impact on their market value.

Ho3. The capital structure at its two portions of debt and equity, of listed commercial banks at Amman stock Exchange, doesn't affect the market value of those firms.

\section{Study Methodology}

The commercial banking industry of Jordan constitutes the population of the study, where 15 commercial local banks were listed at ASE by the end of 2020, among these, two are Islamic banks. Because Islamic banks apply the regulations of Islam, some differences in procedures, between Islamic and number of common shares outstanding by the share market value. Only two independent variables are taken into consideration in the study including, debt, and equity. To be more consistent, the actual values of debt and equity had been used in the analysis, because no indicator is found to be more appropriate than the bank market value itself, for bank market value determination. Actually, several measures can be used to measure the debt such as debt ratio, debt to equity ratio, and longterm debt ratio. Debt ratio is used in the study $\mathrm{MV}=\mathrm{a}+\mathrm{bD}+\mathrm{E}$

Where MV refers to banks market value, D refers to debt ratio, whereas, a is a constant, and used in the study to represent the market value when debt equals zero, and $b$ is aconstant, and used to represnt slope of market value on debt. In other words, b represents the oter nonislamic commercial banks, are available. Because of few procedural differences in details, the islamic banks are excluded, and only the data of the nonislamic banks of Jordan was collected and used in analysis and hypothesestesting.. Therefore, the remaining 13 banks was taken into consideration. Several conditions had been identified for the included commercial banks in the study sample. To be within the study sample, a commercial bank should meet several conditions. Each commercial included bank within the study sample, should be listed regularly at ASE since 2010 till 2020. Moreover, the required information that satisfy the needs of the study, should be available, without a shortage, and each included bank was not subject to sanctions by the Jordanian Securities Exchange Commission, along the study period.

The required data to the study is secondary in nature, and the dataattributed to each commercial included bank was collected through annual report of ASE..Data covering the period 2010-20189, had been collected throgh the annual report of ASE, and used in hypotheses testing.

The dependent variable of the study is the market value, where the bank market value can be determined by multiplying the bank's

because it is based on debt relationship to total assets. Debt ratio iscomputed by dividing total liabilities by total assets.

Based on the structure of variables that mentioned above, and taking into consideration the assumed relationships among the dependent an independent variables, the regression model is developed to enable testing the first hypothesis as follows.

$\mathrm{MV}=\mathrm{a}+\mathrm{bQ}+\mathrm{E}$

change in the market value resulting from the change in debt. In occasion $\mathrm{E}$ denotes for the random error.

The following regression model is used to represent the assumed impact of equity on firm market value in the second hypothesis.

$$
\mathrm{MV}=\mathrm{a}+\mathrm{bQ}+\mathrm{E}
$$


Where MV, a, b, and E refer for the same it refers for, in equation 1 , and $\mathrm{Q}$ refers to equity. The regression model that is used to enable testing the capital structure in its two portions; debt and equity, is developed and appearing as follows

$\mathrm{MV}=\mathrm{a}+\mathrm{bD}+\mathrm{CQ}+\mathrm{E}$

In addition to the descriptive statistics that used to describe the data, the ordinary least square method is used in testing the entire hypotheses of the study. The hypotheses of the study are tested under 95 percent level of confidence, where in this case the coefficient of significance will be 5 percent. Therefore, the null hypotheses is accepted when the computed coefficient of significance is greater than 0.05 , and it is rejected when the computed coefficient of significance equals or less than 0.05. In addition to the coefficient of

\section{Results and Analysis}

The accompanying appendix A includes the data that is used in data analysis and hypotheses testing. When the debt ratio is computed, it is found that, the ratio of total liabilities to total assets (debt ratio) is between $85 \%$ to $90 \%$ along the period of the study, of all banks, with few differences from one bank to another. This ratio is due to the regulations of the Central Bank of Jordan, where the regulations of Basel Committee on Banking Supervision should be followed (Basel Committee on Banking Supervision, 2018).

No large differences in debt ratio among firms or from year to year for the same bank. The data analysis showed low equity and high debt in all included banks in the sample. Actually, the phenomenon of high debt and low equity is extended to all commercial banks in different developing and developed countries, and it is related to the nature of work in commercial banks, where commercial banks accept deposits and grant loans, opens different types of accounts, and provide different banking services to customers.

\subsection{Hypotheses Testing}

As mentioned above, the ordinary least squares method had been used in testing the hypotheses of the study, and all hypotheses were tested under 95 percent level of confidence, or at 0.05 (1-0.95) coefficient of confidence. significance as a decision-making base, another decision making base is used, trough the comparison between the computed and the corresponding tabulated t-values. Based on the comparison between the computed and the tabulated t-value decision base, the null hypothesis is accepted when the computed tvalue is less than its corresponding tabulated one. In opposite, the null hypothesis is rejected, and instead, its alternative one is accepted, when the computed $t$-value is higher than its corresponding tabulated one.

The null form of the first hypothesis states that debt has no impact on the bank market value. The hypothesis is presented again as follows..

Ho1. The debt portion in the capital structure of the listed commercial banks at Amman Stock Exchange, has no impact on the market value of banks.

Table (1) shows the statistics that are related to the impact of debt on bank market value. As appearing in the table, the computed t-value equals 36.098 and the computed coefficient of significance equals zero. When the computed t-value is compared with its corresponding tabulated one, which equals 1.96, it is apparent that the computed one is higher, and when the computed coefficient of significance is compared with its corresponding predetermined one, which equals 0.05 , it is apparent that the computed one is less. Because the computed t-value is higher than the tabulated, and because the computed coefficient of significance is less than the predetermined one, the null hypothesis is rejected, and instead, the alternative one, which states that debt affects the market value, is accepted. This result means that the bank market value is significantly affected by debt, despite that the primary findings of Modigliani-Miller theorem (1958) showed no effect under assumptions of no tax and zero transaction cost. This result can't be considered in agreement with Modigliani-Miller theorem, because all commercial banks of Jordan are 
Table 1

Statistics related to the impact of debt on bank market value

\begin{tabular}{|c|c|c|c|c|c|c|}
\hline \multicolumn{2}{|c|}{ Hypothesis } & \multicolumn{2}{|c|}{$\begin{array}{c}\text { Unstandardized } \\
\text { Coefficients }\end{array}$} & $\begin{array}{c}\text { Standardize } \\
\text { d } \\
\text { Co }\end{array}$ & \multirow{2}{*}{ t } & \multirow{2}{*}{ Sig. } \\
\cline { 3 - 6 } & & B & Std. Error & Beta & & \\
\hline Ho1 & Constant & $-\mathbf{3 . 9 1 8 E} 7$ & $\mathbf{3 . 5 9 3 E}$ & & $\mathbf{- 1 . 0 9 0}$ & $\mathbf{0 . 2 7 8}$ \\
\hline & Debt & $\mathbf{0 . 2 0 5}$ & $\mathbf{0 . 0 0 6}$ & $\mathbf{0 . 9 5 4}$ & $\mathbf{3 6 . 0 9 8}$ & $\mathbf{0 0 0}$ \\
\hline
\end{tabular}

Therefore, the regression model will be as follows.

$$
\mathrm{MV}=-3.918 \mathrm{E} 7+0.205 \mathrm{D}+0.006
$$

The null form of the second hypothesis states that equity has no effect on the bank market value. The hypothesis is presented again as follows.

Ho2. The equity portion in the capital structure of listed commercial banks at Amman Stock Exchange, has no impact on their market value.

Table (2) shows the statistics that are related to the impact of equity on bank market value. As shown in the table, the computed t-value equals 35.346 and the computed coefficient of significance equals zero. When the computed t-value is compared with its corresponding tabulated one, which equals 1.96, it is apparent that the computed one is higher, and when the computed coefficient of significance is compared with its corresponding predetermined one, which equals 0.05 , it is apparent that the computed one is less. Because the computed $t$-value is higher than the tabulated, and because the computed coefficient of significance is less than the predetermined one, the null hypothesis is rejected, and the alternative one, which states that equity affects the bank market value, is accepted. This result means that the bank market value is significantly affected by equity portion in the capital structure.

Table 2

Statistics related to the impact of debt on bank market value

\begin{tabular}{|l|c|c|c|c|c|c|}
\hline \multicolumn{2}{|c|}{ Hypothesis } & \multicolumn{2}{c|}{$\begin{array}{c}\text { Unstandardized } \\
\text { Coefficients }\end{array}$} & $\begin{array}{c}\text { Standardize } \\
\text { d } \\
\text { Co }\end{array}$ & \multirow{2}{*}{ t } & \multirow{2}{*}{ Sig. } \\
\cline { 3 - 5 } \multicolumn{2}{|c|}{} & B & Std. Error & Beta & & \\
\hline \multirow{2}{*}{ Ho2 } & Constant & $\mathbf{1 . 6 5 9 E 7}$ & $\mathbf{3 . 5 8 1 E 7}$ & & $\mathbf{0 . 4 6 3}$ & $\mathbf{0 . 6 4 4}$ \\
\cline { 2 - 7 } & Debt & $\mathbf{1 . 1 6}$ & $\mathbf{0 . 0 3 3}$ & $\mathbf{0 . 9 5 2}$ & $\mathbf{3 5 . 3 4 6}$ & $\mathbf{0 0 0}$ \\
\hline
\end{tabular}

As a result, and based on the related statistics to the impact of equity on the bank market value, the regression model is appearing as follows.

$\mathrm{MV}=1.161+0.033 \mathrm{Q}+$
$3.581 \mathrm{E} 7$

Capital structure including its both components; debt and equity, is an independent important variable in the study.
To enable testing the effect of capital structure on bank market value, the third hypothesis had been stated above, but it is again presented, in its null form, as follows.

Ho3. The capital structure at its two portions of debt and equity, of listed commercial banks at Amman stock Exchange, doesn't affect the market value of those banks.

Table 3 shows the relevant statistics regarding the impact of capital structure on bank market value. The table shows that the computed 
coefficient of significance equals zero and the computed t-value equals 36.326. When the computed coefficient is compared with the predetermined one, which equals 0.05 , it is found the computed one is less than its apparent that the computed one is higher. Because the computed coefficient of significance is less than the predetermined, and because the computed t-value is higher than the tabulated one, the null hypothesis is rejected, where instead, its alternative one, corresponding predetermined one. Moreover, when the computed t-value is compared with its corresponding tabulated one, which equals 1.96 ,

it is

which states that capital structure affects the bank value, is accepted. This result means that the capital structure, which consists of the total of debt and equity together, has a significant positive effect on banks market value.

Table 3: , Statistics related to the impact of debt on bank market value

\begin{tabular}{|c|c|c|c|c|c|c|}
\hline \multicolumn{2}{|r|}{ Hypothesis } & \multicolumn{2}{|c|}{$\begin{array}{l}\text { Unstandardized } \\
\text { Coefficients }\end{array}$} & \multirow{2}{*}{$\begin{array}{c}\begin{array}{c}\text { Standardize } \\
\text { d } \\
\text { Co. }\end{array} \\
\text { Beta }\end{array}$} & \multirow{2}{*}{$\mathrm{t}$} & \multirow{2}{*}{ Sig. } \\
\hline & & B & $\begin{array}{l}\text { Std. } \\
\text { Error }\end{array}$ & & & \\
\hline \multirow[t]{2}{*}{ Ho3 } & Constant & $\begin{array}{l}- \\
3.200 E 7\end{array}$ & $3.561 E 7$ & & -0.899 & 0.371 \\
\hline & Capital Structure & 0.174 & 0.005 & 0.955 & 36.326 & 000 \\
\hline
\end{tabular}

Based on the results of hypotheses testing, the model representing the impact of the entire capital structure is being as follows.

$\mathrm{MV}=-3.200 \mathrm{E} 7+0.0174 \mathrm{C}+3.561 \mathrm{E} 7$

\section{Conclusions}

Modigliani-Miller theorem (1958), stated that debt component in the firm capital structure is irrelevant to the market value. The study comes to investigate whether this finding is valid regarding the commercial banking industry of Jordan. To achieve this objective, data covering 10 years (2010-2019) regarding debt, equity, capital structure, and market value of 13 listed banks at ASE, had been collected, analyzed, and tested. Using the ordinary least squares method, the study reveals that each of debt, in the capital structure of listed commercial banks of Jordan, has a significant effect on the market value of commercial banks of Jordan, and also equity positively affects the bank market value. Moreover, the study demonstrates that, the entire capital structure has a negative significant effect on the market value of commercial banks. The findings of the study are not in conflict with Modigliani-Miller theory, when taking into consideration that te ideas of Modigliani-Miller 1958, were reached under an assumption of zero tax. Later on 1963, Modigliani-Miller adjusted their findings of 1958, and stated that debt is relevant to market value when firms are subject to tax. Therefore, because commercial banks of Jordan, as of other firms, are subject to tax, and the data were analyzed for banks that are subject to tax.

The findings of the study are consistent with the findings of Modigliani-Miller, (1958), Maxwell and Kehinde (2012), Adeyemi and Oboh (2011), Aggarwal and Padhan, (2017), and Al-Nsour and Al-Muhtadi . Moreover, Ahmeti and Prenaj (2015) found that the can't prove that capital structure is completely irrelevant to firm market value. In opposite, Al-Slehat (2020), found that financial leverage doesn't affect the market value of firms. The findings contributes in accumulted knowledge, and the study adds more credibility since it confirmed the themes of Modigliani-Miller Theorem. Based on these finding, more studies of the determinants of market value, including debt and capital structure, are 
strongly recommended to be done in this context.

\section{References}

[1] Adeyem, S .B., and Oboh, C. S. (2011). Perceived Relationship Between Corporate Capital Structure and Firm Value in Nigeria, International Journal of Business and Social Science, Vol. 2, No. 19, 2011, pp. 131-143.

[2] Aggarwal, D., and Padhan, P. C. (2017). Impact of Capital Structure on Firm Value:Evidence from Indian Hospitality Industry, Scientific Research Publishing, Vol. 7, No. 4, 2017,pp. 9821000 .

[3] Ahmeti, F., and Prenaj, B. A, Critical Review of Modigliani and Miller's Theoremof Capital Structure, International Journal of Economics, Commerce and Management, Vol. 3,No. 6, 2015, pp. 914924.

[4] Ajanthan, A., Capital Structure and Financial Performance: A Study of Listing Trading Companies in Sri Lanka, Academicia, Vol. 3, No. 6, 2009, pp. 1-13.

[5] Al-Nsour, O., and Al-Muhtadi, A., Capital Structure, Profitability and Firm'sValue: Evidence from Jordan, Research Journal of Finance and Accounting, Vol. 10, No. 20, 2019, pp. 7380.

[6] Al-Slehat, Z., Impact of Financial Leverage, Size and Assets Structure on Firm Value: Evidence from Industrial Sector, Jordan, International Business Research, Vol. 13, No. 1, 2020, pp. 109120.

[7] Antwi, S., Mills, E.F., and Zhao, P. X, Capital Structure and firm Value: Empirical Evidence from Ghana, International Journal of Business and Social Science, Vol, 3, No. 22, 2012, pp. 103-111.
[8] Baker, M., and Wurgler, J., Market Timing and Capital Structure, Journal of Finance, Vol. 57, No. 1, 2012, pp. 315320.

[9] Bao, G., Zeng, F., \& Wang, M., Study on Human Resource Allocation Efficiency Based on DEA Analysis, International Journal of Circuits, Systems and Signal Processing, Vol. 14, 2017, pp. 1136-1141.

[10] Basel Committee on Banking Supervision, Instructions for Basel III Monitoring, 2018, Available on Line at: https://www.bis.org/bcbs/qis/biiiimplmoni nstr_oct18.pdf.

[11] Collins, O. S., Filibus, I. E, and Clement, A. A., Corporate Capital Structure andCorporate Market Value: Empirical Evidence from Nigeria, International Journal of Economics and Finance, Vol. 4, No. 12, 2012, pp. 193201.

[12] Duan, X., Systematic Risk Measurement Based on CoVaR Model, International Journal of Circuits, Systems and Signal Processing, Vol. 13, 2019, pp. 243-250..

[13] Enow, A. B., A Study of Capital Structure in Extremely Different Environments, Master Thesis, Blekinge Institute of Technology, 2010, Available on Line at: https://www.divaporta.org/smash/get/diva2:833012.

[14] Jensen, M. C., Agency Costs of Free Cash Flow, Corporate Finance and Takeovers, American Economic Review, Vol. 6, No. 2, 1986, pp. 323-329.

[15] Luigi, P., and Sorin, V., A Review of the Capital Structure Theories, 2009, Available on Line at: file://C:/Users/pc/Downloads/53\%20(1).p df.

[16] Maxwell, O. O., and Kehinde, E. F., Capital Structure and Firm Value: 
EmpiricalEvidence from Nigeria, International Journal of Business and Social Science, Vol. 3, No. 9, 2009, pp.252-261.

[17] Modigliani, F., and Miller, M. H., The Cost of Capital, Corporate Finance and the Theory of Investment, American Economic Review, Vol. 48, No. 1, 1958, pp. 61-297.

[18] Myers, S. C., The Capital Structure Puzzle, Journal of Finance, Vol. 39, No. 3, 1984. Pp. 575- 592.

[19] Myers, S. C., and Najulf, N. S., Corporate Financing and Investment Decision When Firms Have Information that Investors Do Not Have, Journal of Financial Economics, Vol. 13, No. 2, 1984, pp. 187-221.

[20] Myers, S. C., Capital Structure: Some Legal and Policy Issues, Discussion Paper, Company Law Reform in OECD Countries: A Comparative Outlook of Current Trends Conference, OECD, 2001, Available on Line at:

https://www.oecd.org/daf/ca/corporategov ernanceprinciples/1857283.pdf.

[21] Nguyen, T. T., et al, The relationship Between Capital Structure and Firm Value:Cases of Listed Companies in the Food and Beverages Industry in Vietnam,
Academy of Accounting and Financial Studies Journal, Vol. 24, No. 1, 2020.

[22] Pouraghajan, A. A., and Bazugir, V., Impact of Capital Structure on Firm Value:Evidence from Teran Stock Exchange, Management Science Letters, Vol. 3, No. 2013, pp. 1535-1538.

[23] Saad, N.M., Corporate Governance Compliance and the Effects to Capitaltructure in Malaysia, International Journal of Economics and Finance 1, Vol. 2, No. 1, 2010, pp. 105-114.

[24] Shanika Ishari, M. P., and Madhushanka Abeyrathna, S. P., The Impact of Financial Leverage on Firms' Value: Special Reference to Listed Manufacturing Firms in Sri Lanka, International Journal of Advancement in Engineering Technology, Management and Applied Science, Nol. 3, No. 7, 2016, pp. 100-104.

[25] Stulz,R., Management Control of Voting Rights: Financing Policies and the Market for Corporate Control, Journal of Finance and Accounting, Vol. 2, No. (4), 1988, pp. 82-99.

[26] Tudor, M., Andrei, A. M, Adrian, Badescu, A., and Georgescu, I., Modigliani-Miller Theorem and Its Implications on Romanian Agricultual Policies, Economics \& Finance, Vol. 13, No. 13, 2014, pp. 101-108.

\section{Creative Commons Attribution License 4.0 (Attribution 4.0 International, CC BY 4.0)}

This article is published under the terms of the Creative Commons Attribution License 4.0

https://creativecommons.org/licenses/by/4.0/deed.en_US 